\title{
Blood-derived topical therapy for ocular surface diseases
}

\author{
Nishant G Soni, Bennie H Jeng
}

Department of Ophthalmology and Visual Sciences, University of Maryland School of Medicine, Baltimore, Maryland, USA

\section{Correspondence to} Professor Bennie H Jeng, Department of Ophthalmology and Visual Sciences, University of Maryland School of Medicine, 419 W. Redwood Street, Suite 470, Baltimore, MD 21201, USA; BJeng@som. umaryland.edu

Received 2 March 2015 Revised 16 June 2015 Accepted 21 June 2015 Published Online First 15 July 2015

\section{ABSTRACT}

Human serum-derived and plasma-derived therapies have become increasingly popular in the treatment of ocular surface disorders, with mounting clinical and scientific evidence suggesting good safety and efficacy profiles. These therapies may be considered for various ocular surface conditions, such as dry eye syndrome and persistent epithelial defect, when conservative management does not suffice. The costly and inconvenient process of obtaining the blood-derived products is the barrier to their more widespread use. Some blood-derived therapies, such as umbilical cord serum-derived and platelet-derived plasma preparations, may be more viable options since these therapies can be made readily available to patients. In this review, the existing literature on the safety and efficacy of bloodderived products, such as autologous serum tears, in the treatment of ocular surface diseases is discussed. Issues relevant to the production of autologous serum tears are also described.

\section{INTRODUCTION}

The health of the ocular surface depends on adequate maintenance of the tear film. The tear film's mucoaqueous and lipid layers provide mechanical protection of the corneal epithelium, while a variety of growth factors, vitamins, electrolytes and neuropeptides support the growth and migration of epithelial cells. ${ }^{1}{ }^{2}$ Tear film abnormalities may occur in states of mucoaqueous deficiency, such as Sjögren's syndrome (SS) and goblet cell destruction, or with ocular adnexal problems, including meibomian gland deficiency and lagophthalmos. In ocular surface disorders, the mechanical and epitheliotrophic characteristics of the tear film are both crucial in preventing further compromise of epithelial integrity and in promoting wound healing.

Traditional, first-line methods of ocular surface disease treatment focus on shielding the epithelium from biomechanical trauma. ${ }^{2}$ Blood-derived therapies additionally contain some of the same growth factors, cytokines, vitamins and nutrients found in natural tears to support epithelial cell homeostasis, growth and migration. ${ }^{3}$ The use of blood-derived therapy for ocular surface disorders was first described in 1975 in a case series by Ralph and colleagues, in which a mobile ocular perfusion pump delivered serum or plasma to the ocular surfaces of six patients. ${ }^{4}$ Fox and associates ${ }^{5}$ then demonstrated the efficacy of autologous serum eye drops (ASE) in the treatment of keratoconjunctivitis sicca. This therapy gained more widespread attention after Tsubota and colleagues published two studies in 1999 showing convincing evidence of the benefits of ASE in SS-related dry eye syndrome
(DES) and persistent epithelial defects (PEDs). ${ }^{6} 7$ Their studies were the first to systematically demonstrate both the efficacy and the safety of ASE.

Since then, clinical research evaluating its effectiveness has expanded greatly ${ }^{8}$ (figure 1). Indications for which blood-derived therapy has been studied include DES caused by various aetiologies, ${ }^{6}$ 9-27 PEDs, ${ }^{7} 142028-34$ recurrent erosion syndrome, ${ }^{35} 36$ chemical injury ${ }^{37} 38$ and superior limbic keratoconjunctivitis. ${ }^{39}$ ASE, allogeneic serum, umbilical cord serum (UCS) and platelet-rich plasma (PRP) have all been studied for use in ocular surface disease. Barriers to their more common use include the potential for sample contamination, inconvenience to the patient of sample preparation and the lack of a standardised protocol for preparation. ${ }^{8}$ This review discusses the literature on human bloodderived treatments for ocular surface disease and surveys current methods for the production of ASE.

\section{AUTOLOGOUS SERUM EYE DROPS}

ASE's biochemical properties are similar to those of human tears. ${ }^{1}{ }^{40}$ Epidermal growth factor (EGF), which increases migration and proliferation of corneal epithelial cells, and transforming growth factor- $\beta$ (TGF- $\beta$ ), which decreases epithelial cell proliferation, are the most important components of tears. ${ }^{3}{ }^{41-43}$ Fibronectin, vitamin A and a variety of chemokines, growth factors and nutrients further contribute to the tear film milieu that maintains the ocular surface. ${ }^{3}$ Fibronectin is present at a concentration of $205 \mu \mathrm{g} / \mathrm{mL}$ in serum compared with a tear film concentration of $21 \mathrm{ng} / \mathrm{mL}^{1}{ }^{1}$ EGF concentrations are similar in serum $(0.7-10 \mathrm{ng} / \mathrm{mL})$ and tears $(0.5 \mathrm{ng} /$ $\mathrm{mL})^{7}$ while vitamin A concentrations are much higher in serum $(46 \mathrm{mg} / \mathrm{mL})$ than in tears $(0.02 \mathrm{mg} /$ $\mathrm{mL}) .{ }^{1}$ More importantly, TGF- $\beta$ concentrations are five times higher in serum than in tears. ${ }^{6}$ Therefore, many ophthalmologists prefer to use a $20 \%$ dilution of ASE to more closely match the TGF- $\beta$ concentration in natural tears in order to prevent problems with epithelial cell proliferation. ${ }^{3} 4044$

\section{Dry eye syndrome}

We found six prospective randomised controlled trials (RCTs) in the literature pertaining to ASE in the treatment of DES (listed in table 1).

The subjects and observers in RCTs on ASE therapy can be difficult to mask, because the placebo, usually artificial tears, is of a different colour than serum, and the viscosity of artificial tears may change after undergoing the freeze-thaw process. ${ }^{46}$ There also tends to be a strong placebo effect, since the artificial tears used in the control groups themselves have alleviating properties. 
Figure 1 The number of peer-reviewed publications related to the use of human blood-related products in the treatment of ocular surface disease from October 1975 to December 2014. The search was conducted using PubMed with the key phrases 'autologous serum tears', 'serum eye drops', 'serum-derived ocular', 'serum-derived eye', 'platelet-rich plasma eye', 'plasma rich in growth factors eye', 'cord serum eye'.

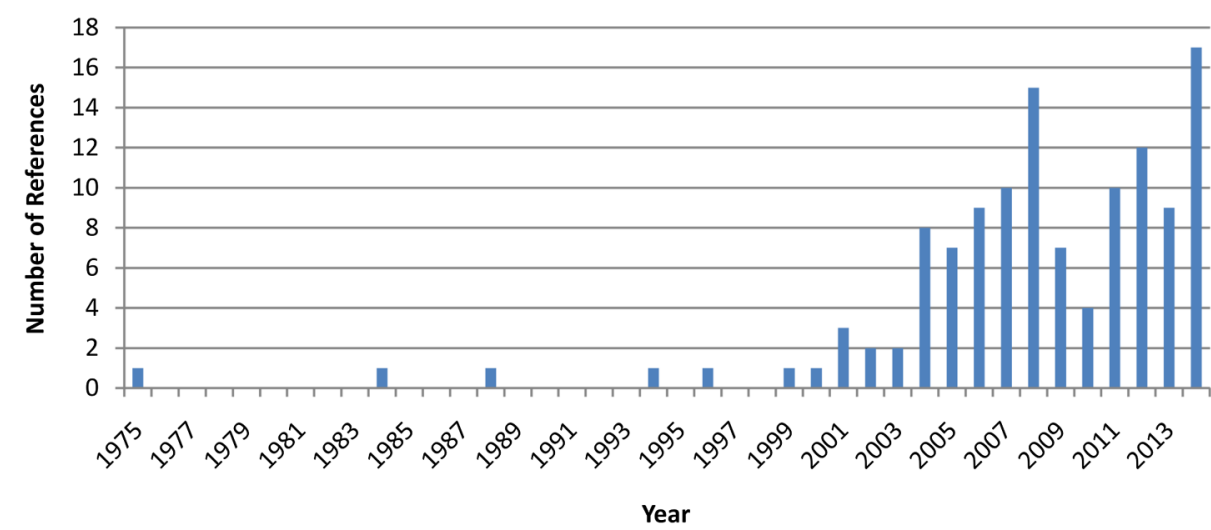

This was shown in the first controlled study by Tananuvat et $a l^{9}$ in 2001, in which 12 patients with bilateral severe dry eye of various aetiologies received artificial tears in one eye and ASE in the other. Although objective and subjective improvements were noted in the treatment eyes at 2 months, control eyes similarly improved, thus negating any differences between artificial tears and serum therapy. The study reported decreased use of concurrent topical lubricants from 11.5 drops per day to 2.15 drops per day, but this trend may have simply represented the necessity of decreasing eye drop frequency when applying ASE six times per day. Noble and colleagues, ${ }^{10}$ in contrast, found significant objective and subjective improvements in DES in their randomised controlled crossover trial including 16 patients with severe dry eye. Conjunctival impression cytology (CIC), performed by a masked pathologist, improved significantly on serum therapy. Dry eye symptoms were found to be managed significantly better after 3 months of serum therapy compared with after 3 months of artificial tears. However, the patients and observers were not masked to the treatments. Kojima and associates $^{11}$ evaluated a shorter treatment length in a study of 20 dry eye patients with SS and without SS. They found that even with a 2-week treatment course, there was a significant improvement in subjective scores as well as tear break-up time (TBUT), rose-bengal staining scores and fluorescein staining scores in the treatment group. A potential shortcoming of this study was that although the observers were masked to which treatment the patients were receiving, the patients were aware of their own treatment group, which could have decreased drop compliance in the control group.

The two most recent RCTs by Urzua and colleagues ${ }^{12}$ and Celebi and associates ${ }^{13}$ employed the Ocular Surface Disease Index (OSDI) to better standardise their results. The OSDI has been validated as a reliable instrument for use in clinical trials. ${ }^{47}$ In the double-blind crossover study by Urzua and colleagues, 12 patients with severe DES were treated with 2 weeks of ASE and found to have no significant improvements in objective measures, including TBUT and OXFORD fluorescein staining score of the cornea. However, OSDI scores were improved after serum therapy by $50.95 \%$, which was significantly better than the improvement on conventional treatment (22.19\%). Celebi and colleagues $^{13}$ corroborated the improvement in OSDI, as in their RCT of 20 patients with severe dry eye, OSDI scores decreased by $55.18 \%$ in the treatment group, compared with a decrease of $19.50 \%$ in the preservative-free artificial tears group.

Overall, the RCTs evaluating ASE for use in DES provide promising data for patients in terms of symptomatic relief of dry eye. More rigorous efforts to blind the subject and observer may decrease the potential for bias in future studies. Sample sizes of the current RCTs in the ASE literature were also too small to make definitive judgements on the efficacy of treatment.

\section{Persistent epithelial defect}

PED was among the first applications of ASE therapy to be studied $^{7}$ and subsequent papers have demonstrated its efficacy in clinical practice. ${ }^{14} 28-32$ Poon and colleagues ${ }^{14}$ reported that out of 15 eyes with PEDs which had previously been treated for a mean length of time of 48.2 days aggressively with botulinum toxin-induced ptosis, bandage contact lenses, tarsorrhaphy and/ or amniotic membrane transplantation, nine $(60 \%)$ healed at a mean of 29 days after initiation of ASE. In another case series of 10 patients with PEDs (mean duration 22.4 days) caused by a variety of aetiologies, 6 (60\%) PEDs healed within 1 week of ASE, while $2(20 \%)$ did not heal by 1 month and 2 patients (20\%) were lost to follow-up. Jeng and Dupps ${ }^{31}$ published on 25 eyes with PEDs of various aetiologies with median duration of 13.9 weeks, of which 23 (92\%) healed within an average of 22.4 days. According to Tsubota and colleagues ${ }^{7}$ grading system, treatment was effective (PED healed within 2 weeks) in 52\% and partially effective (PED healed within 4 weeks) in $68 \%$ of cases. In this study, the longer the duration of the PED, the longer it took to heal with ASE therapy. Treatment of PED with a combination of ASE and silicone hydrogel contact lenses has also been explored. $^{29}{ }^{32}$ Schrader and collagues ${ }^{29}$ found that of six eyes with PEDs previously unsuccessfully treated, five (83.3\%) healed within 1 month. Of note, an amorphous coating of nodular deposits was noted in three of these eyes and thought due to albumin protein deposition, which comprises $60 \%$ of serum protein content. No signs of infection were noted.

Based on the current literature, ASE therapy seems to be quite effective in the treatment of PEDs, but study sample sizes have been very small. As ASE preparations usually do not contain preservative, one must pay heed to the theoretically increased infection risk that could arise with a serum-derived product in the setting of an epithelial defect.

\section{ASE production issues \\ Protocols}

The process of ASE production varies and involves the collection of whole blood from patients, clotting, centrifugation, collection of the supernatant and dilution of the supernatant. According to a questionnaire about ASE production methods completed by 13 hospitals in Korea, amount of blood collected, clotting time, centrifugation speed and time, as well as per cent dilution and diluents differed between the hospitals. ${ }^{48}$ The NHS Blood and Transplant of Great Britain has employed a 
Table 1 Characteristics and outcomes of controlled clinical trials on autologous serum eye drop therapy in dry eye syndrome (DES)

\begin{tabular}{|c|c|c|c|c|c|c|c|c|c|c|c|}
\hline Study & Reference & $\begin{array}{l}\text { Underlying } \\
\text { diagnoses }\end{array}$ & $\begin{array}{l}\text { Number } \\
\text { of eyes/ } \\
\text { patients }\end{array}$ & Masking & Placebo & $\begin{array}{l}\text { Dilution } \\
\text { (\%) }\end{array}$ & Frequency & $\begin{array}{l}\text { Treatment } \\
\text { length }\end{array}$ & $\begin{array}{l}\text { Concurrent } \\
\text { therapy }\end{array}$ & $\begin{array}{l}\text { Objective } \\
\text { tests }\end{array}$ & $\begin{array}{l}\text { Subjective } \\
\text { tests }\end{array}$ \\
\hline 1 & Tananuvat et $a l^{9}$ & $\begin{array}{l}\text { SS, NHL, } \\
\text { GVHD, SJS, } \\
\text { RA }\end{array}$ & $24 / 12$ & Single (patient) & $\begin{array}{l}\text { Unpreserved } \\
\text { saline } \\
\text { solution (with } \\
\text { dilute } \\
\text { fluorescein) }\end{array}$ & 20 & $6 \times /$ day & 2 months & $\begin{array}{l}\text { Punctal } \\
\text { occlusion, } \\
\text { PFAT }\end{array}$ & $\begin{array}{l}\text { TBUT, RBS, } \\
\text { FS, CIC }\end{array}$ & $\begin{array}{l}\text { Symptom } \\
\text { score }\end{array}$ \\
\hline 2 & Noble et $a l^{10}$ & $\begin{array}{l}\text { GVHD, SS, } \\
\text { OCP, BS, } \\
\text { RDS }\end{array}$ & $31 / 16$ & $\begin{array}{l}\text { Pathologist } \\
\text { conducting CIC } \\
\text { only }\end{array}$ & $\begin{array}{l}\text { Pt"s previous } \\
\text { conventional } \\
\text { treatment }\end{array}$ & 50 & Varied & 3 months & None & $\begin{array}{l}\text { RBS, FCT, } \\
\mathrm{CIC}\end{array}$ & Faces Scale \\
\hline 3 & Kojima et al ${ }^{11}$ & SS, non-SS & $37 / 20$ & Examiner only & PFAT & 20 & $6 \times /$ day & 2 weeks & None & $\begin{array}{l}\text { TBUT, RBS, } \\
\text { FS, CIC }\end{array}$ & $\begin{array}{l}\text { Visual } \\
\text { analogue } \\
\text { pain } \\
\text { symptom } \\
\text { score }\end{array}$ \\
\hline 4 & Noda-Tsuruya et a/ ${ }^{45}$ & $\begin{array}{l}\text { Post-LASIK } \\
\text { dry eyes }\end{array}$ & $54 / 27$ & $\mathrm{~N} / \mathrm{A}$ & Artificial tears & 20 & $5 \times /$ day & 6 months & None & $\begin{array}{l}\text { TBUT, RBS, } \\
\text { FS }\end{array}$ & $\begin{array}{l}\text { Subjective } \\
\text { scores }\end{array}$ \\
\hline 5 & Urzua et $a l^{12}$ & $\begin{array}{l}\text { Non-SS } \\
\text { severe DES, } \\
\text { age-related } \\
\text { dry eye }\end{array}$ & 12 pts & Double-masked & Artificial tears & 20 & $4 \times /$ day & 2 weeks & None & TBUT, FS & OSDI score \\
\hline 6 & Celebi et $a l^{13}$ & Severe DES & $40 / 20$ & Double-masked & PFAT & 20 & $4 \times /$ day & 1 month & None & $\begin{array}{l}\text { TBUT, } \\
\text { Schirmer, } \\
\text { Oxford score }\end{array}$ & OSDI score \\
\hline
\end{tabular}

\begin{tabular}{|c|c|c|c|c|c|}
\hline Study & Reference & Objective improvement & Subjective improvement & Failure rate & Complications \\
\hline 1 & Tananuvat et al $l^{9}$ & $33 \%(\mathrm{RB}), 39 \%(\mathrm{FS})$ & $36 \%$ (symptom score) & $\mathrm{N} / \mathrm{A}$ & $\begin{array}{l}1 \text { bottle positive } \\
\text { cultures, } \\
2 \text { conjunctivitis pts }\end{array}$ \\
\hline 2 & Noble et $a l^{10}$ & $48 \%$ of pts (CIC) & $75 \%$ of pts & $\begin{array}{l}3 / 16 \text { pts—objective }(19 \%) \\
13 / 25 \text { eyes—-subjective }(52 \%)\end{array}$ & None \\
\hline 3 & Kojima et al ${ }^{11}$ & $\begin{array}{l}\text { TBUT, RB and FS scores statistically improved in } \\
\text { tx group }\end{array}$ & $\begin{array}{l}\text { Statistically significant improvement } \\
\text { after treatment }\end{array}$ & N/A & Not mentioned \\
\hline 4 & Noda-Tsuruya et $a l^{45}$ & $\begin{array}{l}\text { TBUT prolonged @ } 6 \text { months, RB @ } 1 \text { and } \\
3 \text { months, FS @ } 1 \text { month }\end{array}$ & No difference before/after surgery & N/A & N/A \\
\hline 5 & Urzua et $a l^{12}$ & No significant improvement in TBUT/FS & $\begin{array}{l}50.95 \% \text { decrease in OSDI } \\
\text { (statistically sig.) }\end{array}$ & N/A & None \\
\hline 6 & Celebi et $a l^{13}$ & $\begin{array}{l}\text { TBUT improved significantly, OXFORD and } \\
\text { Schirmer's did not }\end{array}$ & $\begin{array}{l}54.74 \% \text { decrease in OSDI score (stat. } \\
\text { sig.) }\end{array}$ & $\mathrm{N} / \mathrm{A}$ & None \\
\hline
\end{tabular}

BS, Behçet's syndrome; CIC, conjunctival impression cytology; FCT, fluorescein clearance test; FS, fluorescein staining; GVHD, graft-versus-host disease; LASIK, laser-assisted in situ keratomileusis; NHL, non-Hodgkins lymphoma; OCP, ocular cicatricial pemphigoid; OSDI, Ocular Surface Disease Index; PFAT, preservative-free artificial tears; RA, rheumatoid arthritis; RBS, rose-bengal staining; RDS, Riley-Day syndrome; SJS, Stevens-Johnson syndrome; SS, Sjögren's syndrome; TBUT, tear break-up time.

standardised method for production of ASE which has been used since $1997 .{ }^{49}$ However, its estimated yearly production cost per patient is US\$4000 per year if a bottle is used and discarded each day. ${ }^{44}$

Few studies have directly compared clinical outcomes of different concentrations of ASE. ${ }^{21} 43$ In Cho and colleagues' prospective study including 141 eyes with a DES or PED, PEDs healed significantly faster with $100 \%$ than with $50 \%$ ASE. $^{23}$ Symptoms and corneal staining, but not TBUT or Schirmer test value, were also better with $100 \%$ than with $50 \%$ ASE at 12 weeks post-treatment in both the Sjögren's and non-Sjögren's groups. Liu and colleagues determined that a long clotting time $(>120 \mathrm{~min})$, centrifugation at $3000 \mathrm{~g}$ for $15 \mathrm{~min}$ and dilution with balanced salt solution at $12.5-25 \%$ best supported cell proliferation, migration and differentiation of corneal epithelial cells. $^{50}$ Based on this work, Partal and Scott ${ }^{44}$ proposed a low-cost protocol that would adhere to the US Food and Drug Administration requirements for ophthalmic use of autologous blood products. The estimated cost to supply 3 months of ASE to a patient in a safe manner, excluding costs of microbial testing, was US\$195.19. Given the relative affordability and scientific plausibility of this protocol, further studies on ASE should use this protocol to determine its clinical performance.

As of now, ASE therapy is not widely accepted as the standard of care in most European countries and the USA, and since insurance plans will rarely cover its costs, patients must pay anywhere between US $\$ 25$ and US $\$ 600$ out of pocket for a 2-3 month supply. The Northern California Kaiser Permanente Health Care System, which covers a population of 3.2 million people, recently began to offer ASE as an insurance-covered benefit. Over a 1-year period, 103 patients were treated with $100 \%$ ASE, and of 30 patients with follow-up within 90 days, $27(90 \%)$ reported an improvement of symptoms. ${ }^{20}$ Only two (6.7\%) patients had transient discomfort with ASE.

\section{Allogeneic preparations of serum eye drops}

Autologous preparation of serum eye drops is inconvenient for the patient, and certain patients may not qualify for ASE treatment because of coexisting medical conditions, such as anaemia. ${ }^{25}$ An allogeneic sample of serum eye drops, on the other hand, can be prepared from already-stored whole blood in 
Table 2 Characteristics and outcomes of clinical reports on allogeneic serum eye drop therapy

\begin{tabular}{|c|c|c|c|c|c|}
\hline Reference & Size & Pathology & Treatment & Result & Complications \\
\hline Chiang et $a^{25}$ & 36 eyes & PED & $\begin{array}{l}100 \% \text { allogeneic serum hourly } \\
\text { (monotherapy) }\end{array}$ & $15(42 \%)$ of PEDs healed within 2 weeks & None \\
\hline Chiang et $a /^{30}$ & 2 patients & $\begin{array}{l}\text { GVHD-related } \\
\text { DES }\end{array}$ & $\begin{array}{l}100 \% \text { allogeneic serum hourly } \\
\text { (monotherapy) }\end{array}$ & $\begin{array}{l}\text { Patient 1: improved symptoms, TBUT and corneal staining at } \\
2 \text { weeks; } \\
\text { Patient 2: improved symptoms, resolution of filamentous } \\
\text { keratopathy at } 1 \text { week }\end{array}$ & None \\
\hline $\mathrm{Na}$ and $\mathrm{Kim}^{17}$ & 16 patients & $\begin{array}{l}\text { GVHD-related } \\
\text { DES }\end{array}$ & $\begin{array}{l}20 \% \text { allogeneic serum } 6-8 \\
\text { times/day (with PFAT) }\end{array}$ & $\begin{array}{l}\text { Improved OSDI score, corneal staining, impression cytology grade } \\
\text { and tear osmolarity at } 4 \text { weeks }\end{array}$ & None \\
\hline Harritshøj et a $\left.\right|^{11}$ & $\begin{array}{l}20 \text { DES patients, } \\
14 \text { PED eyes }\end{array}$ & PED and DES & $\begin{array}{l}20 \% \text { allogeneic serum } \\
\text { (frequency not specified) }\end{array}$ & $\begin{array}{l}80 \% \text { (16) DES patients with improved symptoms and corneal } \\
\text { staining, no subjective or objective effects on PED group at } \\
4 \text { weeks }\end{array}$ & None \\
\hline
\end{tabular}

approximately $30 \mathrm{~min} .{ }^{51}$ Table 2 shows data with regard to the use of allogeneic serum eye drops.

$\mathrm{ABO}$ antigens are known to exist on conjunctival and corneal surfaces, which may theoretically lead to an inflammatory reaction due to anti-A and anti-B antibodies in allogeneic serum. ${ }^{52}$ However, three of the four studies on allogeneic serum eye drops did not consider $\mathrm{ABO}$ blood type matching in their methods, and no adverse reactions were noted to occur. In New Zealand, where $39 \%$ of serum eye drops used since 2007 have been allogeneic, blood type $\mathrm{AB}$ donors whose serum therefore lacked anti-A and anti-B antibodies have been used in 73 patients with no reported adverse reactions. ${ }^{53}$ Given the potential of allogeneic serum to be as effective as autologous serum in the treatment of DES and PEDs, and its demonstrated safety without the need for matching donors with recipients, allogeneic serum may be a viable alternative to autologous serum in ocular surface disease management if more rigorously studied.

\section{Complications}

Preservatives are typically not added to ASE preparations because they can potentially cause epithelial toxicity. The high protein content of ASE may also predispose samples to microbial contamination. ${ }^{54}$ Clinical infection of the ocular surface by ASE was reported by Rocha and colleagues ${ }^{16}$ and Poon and colleagues ${ }^{14}$ in 2000 and 2001, respectively. Since then, there have been no known reported cases of ocular surface infections attributed to ASE. Reported rates of ASE sample contamination vary widely from $0 \%$ to $55 \%$, and there was no trend towards higher rates of contamination at higher ASE concentrations. ${ }^{54-59}$ Lopez-Garcia and Garcia-Lozano found that adding sterilising filters to ASE containers decreased the contamination rate from $29 \%$ to $2 \%$, thus decreasing the chances of clinical infection even further. ${ }^{59}$ Based on studies conducted by Fischer and colleagues ${ }^{58}$ and Bradley and colleagues ${ }^{60}$ to assess the biological stability of growth factors in ASE, it is recommended that samples be stored at $-20^{\circ} \mathrm{C}$ for up to 6 months, and that single daily-use dropper containers be stored at $4^{\circ} \mathrm{C}$ between doses. Although clinical infection from ASE use is rare, possibly owing to immunologically active components within the serum, patients on ASE therapy, especially those simultaneously on topical steroids, should be closely monitored for signs of infection. $^{56}$

Other complications from ASE use are similarly rare. McDonnell and associates described a patient who developed immunoglobulin deposition in the corneal stroma after application of ASE for 1 week for PED. ${ }^{61}$ Limbitis secondary to ASE use was reported by Welder and colleagues ${ }^{62}$ in a patient treated with ASE for atopic keratoconjunctivitis, which quickly resolved after the discontinuation of treatment.

\section{UMBILICAL CORD SERUM}

UCS contains many of the same growth factors and components as natural tears, including EGF and vitamin A. ${ }^{33}$ UCS may serve as a viable alternative in patients who are not good candidates for ASE therapy, such as those with graft-versus-host disease (GVHD) or SS, where pro-inflammatory cytokines could be present in the serum. ${ }^{63}$ UCS has potential applications in the treatment of PEDs, ${ }^{33}$ GVHD-associated dry eye, ${ }^{18}$ SS-type DES, ${ }^{19}$ recurrent corneal erosions ${ }^{35}$ and chemical burns. ${ }^{37} 38$ Yoon and colleagues demonstrated that UCS eye drops were even more effective than ASE in terms of symptom and keratoepitheliopathy scores in a group of 92 eyes with severe DES at 1 and 2 months post-treatment initiation. ${ }^{19}$ Recurrent corneal erosions were also more effectively managed with UCS eye drops than with artificial tears alone in another study by Yoon and colleagues. ${ }^{35}$ A comparison study of UCS versus ASE and artificial tears in the treatment of ocular chemical burns found UCS-treated patients to require significantly less days to complete corneal epithelialisation than those treated with ASE or artificial tears. ${ }^{38}$ Since one sample of UCS may be distributed to many patients, preparation of samples can be done in advance and made readily available to patients. However, UCS samples must be rigorously screened for bloodborne infections prior to donation.

\section{PLATELET-DERIVED PLASMA PREPARATIONS}

Platelet-derived plasma preparations have been used successfully in oral and maxillofacial surgery and orthopaedics to aid in wound healing, because of the high levels of growth factors found in platelets. ${ }^{64-66}$ Preparation methods of these solutions for ocular use vary in the literature. Whole blood samples are typically obtained, an anticoagulant is added and platelet membranes are disturbed by centrifugation with subsequent retrieval of a supernatant (plasma), which contains the growth factors. $^{34}$ 67-75 'Platelet releasate' contains growth factors released from platelets by thrombin. ${ }^{68}$ 'Plasma rich in growth factors' (PRGF) does not include thrombin. ${ }^{69} 71$ 'Platelet-rich plasma' is produced with an additional centrifugation step. ${ }^{70}$

Promising in vitro and animal model data on platelet-derived plasma preparations led to the initiation of clinical studies evaluating their effects on PEDs and DES. ${ }^{34}$ 68-71 7475 Lopez-Plandolit and associates saw a PED healing rate of $85 \%$ of patients (17 of 20 eyes) in an average of 10.9 weeks on treatment with PRGF. ${ }^{75}$ Of note, six of the patients in their study 
were previously unsuccessfully treated with ASE. However, additional treatments were continued in most patients, two patients required lateral tarsorrhaphy and one required an amniotic membrane graft, thus making it somewhat difficult to assess whether there was an isolated effect of PRGF. Importantly, this study demonstrated the tolerability of PRGF, as only one patient had ocular discomfort requiring discontinuation. Plateletderived plasma therapy's efficacy in PEDs was also compared with that of ASE in a clinical study of 28 eyes with PEDs from infectious keratitis. ${ }^{34}$ All 11 eyes treated with PRP achieved complete re-epithelialisation, whereas only 12 of 17 achieved the same in the ASE group. Healing rates were also faster in the PRP group, a difference which nearly reached statistical significance $(p=0.059)$. Lopez-Plandolit's group also studied 16 patients with moderate to severe DES who received PRGF treatment for at least 3 months. ${ }^{74}$ Symptomatic improvement was noted, with a significant decrease in Dry Eye Questionnaire score after treatment, but objective findings, including lissamine green dye staining and CIC, were not affected by treatment.

Although evaluation of platelet-derived plasma therapies for ocular surface disease is currently in its early stages, these therapies have a good safety profile and may have superior efficacy when compared with ASE in the treatment of PEDs.

\section{CONCLUSIONS}

The use of human blood-derived therapies for treatment of ocular surface disorders has become more popular with clinical and scientific evidence that suggests good safety and efficacy profiles. Early application of such therapy may be warranted in certain situations. Barriers to their more widespread use include cost and the inconvenient process of obtaining the products. Some blood-derived therapies, such as UCS and platelet-derived plasma preparations, may be more viable options since these therapies can be made readily available to patients. Further research using standardised protocols for the production of blood-derived treatments will provide more definitive data on their efficacy, and may ultimately lead to more widespread acceptance of these therapies in everyday practice.

Contributors $\mathrm{BHJ}$ was commissioned to write this review. The initial draft was prepared by NGS under the direct supervision of BHJ, and critical revision was provided by BHJ over multiple revisions.

Competing interests None declared.

Provenance and peer review Commissioned; externally peer reviewed.

\section{REFERENCES}

1 Geerling G, Maclennan S, Hartwig D. Autologous serum eye drops for ocular surface disorders. Br J Ophthalmol 2004;88:1467-74.

2 Rauz S, Saw VP. Serum eye drops, amniotic membrane and limbal epithelial stem cells_-tools in the treatment of ocular surface disease. Cell Tissue Bank 2010;11:13-27.

3 Yamada C, King KE, Ness PM. Autologous serum eyedrops: literature review and implications for transfusion medicine specialists. Transfusion 2008;48:1245-55.

4 Ralph RA, Doane MG, Dohlman CH. Clinical experience with a mobile ocular perfusion pump. Arch Ophthalmol 1975;93:1039-43.

5 Fox RI, Chan R, Michelson JB, et al. Beneficial effect of artificial tears made with autologous serum in patients with keratoconjunctivitis sicca. Arthritis Rheum 1984;27:459-61.

6 Tsubota K, Goto E, Fujita H, et al. Treatment of dry eye by autologous serum application in Sjögren's syndrome. Br J Ophthalmol 1999:83:390-5.

7 Tsubota K, Goto E, Shimmura S, et al. Treatment of persistent corneal epithelial defect by autologous serum application. Ophthalmology 1999;106:1984-9.

8 Jeng BH. Use of autologous serum in the treatment of ocular surface disorders. Arch Ophthalmol 2011;129:1610-12.

9 Tananuvat N, Daniell M, Sullivan LJ, et al. Controlled study of the use of autologous serum in dry eye patients. Cornea 2001;20:802-6.
10 Noble BA, Loh RS, MacLennan S, et al. Comparison of autologous serum eye drops with conventional therapy in a randomised controlled crossover trial for ocular surface disease. Br J Ophthalmol 2004;88:647-52.

11 Kojima $T$, Ishida R, Dogru $M$, et al. The effect of autologous serum eyedrops in the treatment of severe dry eye disease: a prospective randomized case-control study. Am J Ophthalmol 2005;139:242-6.

12 Urzua CA, Vasquez DH, Huidobro A, et al. Randomized double-blind clinical trial of autologous serum versus artificial tears in dry eye syndrome. Curr Eye Res 2012;37:684-8

13 Celebi AR, Ulusoy C, Mirza GE. The efficacy of autologous serum eye drops for severe dry eye syndrome: a randomized double-blind crossover study. Graefes Arch Clin Exp Ophthalmol 2014;252:619-26.

14 Poon AC, Geerling G, Dart JK, et al. Autologous serum eyedrops for dry eyes and epithelial defects: clinical and in vitro toxicity studies. $\mathrm{Br} J$ Ophthalmol 2001;85:1188-97.

15 Ogawa $Y$, Okamoto $S$, Mori T, et al. Autologous serum eye drops for the treatment of severe dry eye in patients with chronic graft-versus-host disease. Bone Marrow Transplant 2003;31:579-83.

16 Rocha EM, Pelegrino FS, de Paiva CS, et al. GVHD dry eyes treated with autologous serum tears. Bone Marrow Transplant 2000;25:1101-3.

17 Na KS, Kim MS. Allogeneic serum eye drops for the treatment of dry eye patients with chronic graft-versus-host disease. J Ocul Pharmacol Ther 2012;28:479-83.

18 Yoon KC, Jeong IY, Im SK, et al. Therapeutic effect of umbilical cord serum eyedrops for the treatment of dry eye associated with graft-versus-host disease. Bone Marrow Transplant 2007;39:231-5.

19 Yoon KC, Heo H, Im SK, et al. Comparison of autologous serum and umbilical cord serum eye drops for dry eye syndrome. Am J Ophthalmol 2007;144:86-92.

20 Dalmon CA, Chandra NS, Jeng BH. Use of autologous serum eyedrops for the treatment of ocular surface disease: first US experience in a large population as an insurance-covered benefit. Arch Ophthalmol 2012;130:1612-13.

21 Phasukkijwatana N, Lertrit P, Liammongkolkul S, et al. Stability of epitheliotrophic factors in autologous serum eye drops from chronic Stevens-Johnson syndrome dry eye compared to non autoimmune dry eye. Curr Eye Res 2011;36:775-81.

22 López-García JS, García-Lozano I, Rivas L, et al. Autologous serum eye drops diluted with sodium hyaluronate: clinical and experimental comparative study. Acta Ophthalmol 2014;92:e22-9.

23 Cho YK, Huang W, Kim GY, et al. Comparison of autologous serum eye drops with different diluents. Curr Eye Res 2013;38:9-17.

24 Versura P, Profazio V, Buzzi M, et al. Efficacy of standardized and quality-controlled cord blood serum eye drop therapy in the healing of severe corneal epithelial damage in dry eye. Cornea 2013;32:412-18.

25 Chiang CC, Lin JM, Chen WL, et al. Allogeneic serum eye drops for the treatment of severe dry eye in patients with chronic graft-versus-host disease. Cornea 2007;26:861-3

26 Hwang J, Chung SH, Jeon S, et al. Comparison of clinical efficacies of autologous serum eye drops in patients with primary and secondary Sjögren syndrome. Cornea 2014;33:663-7.

27 Hussain M, Shtein RM, Sugar A, et al. Long-term use of autologous serum 50\% eye drops for the treatment of dry eye disease. Cornea 2014;33:1245-51.

28 Young AL, Cheng AC, Ng HK, et al. The use of autologous serum tears in persistent corneal epithelial defects. Eye (Lond) 2004;18:609-14.

29 Schrader S, Wedel T, Moll R, et al. Combination of serum eye drops with hydroge bandage contact lenses in the treatment of persistent epithelial defects. Graefes Arch Clin Exp Ophthalmol 2006;244:1345-9.

30 Chiang CC, Chen WL, Lin JM, et al. Allogeneic serum eye drops for the treatment of persistent corneal epithelial defect. Eye (Lond) 2009;23:290-3.

31 Jeng BH, Dupps WJ Jr. Autologous serum $50 \%$ eyedrops in the treatment of persistent corneal epithelial defects. Cornea 2009;28:1104-8.

32 Choi JA, Chung SH. Combined application of autologous serum eye drops and silicone hydrogel lenses for the treatment of persistent epithelial defects. Eye Contact Lens 2011;37:370-3.

33 Yoon KC, Heo $\mathrm{H}$, Jeong IY, et al. Therapeutic effect of umbilical cord serum eyedrops for persistent corneal epithelial defect. Korean J Ophthalmol 2005; 19:174-8.

34 Kim KM, Shin YT, Kim HK. Effect of autologous platelet-rich plasma on persistent corneal epithelial defect after infectious keratitis. Jpn J Ophthalmol 2012;56:544-50.

35 Yoon KC, Choi W, You IC, et al. Application of umbilical cord serum eyedrops for recurrent corneal erosions. Cornea 2011;30:744-8.

36 Ziakas NG, Boboridis KG, Terzidou C, et al. Long-term follow up of autologous serum treatment for recurrent corneal erosions. Clin Experiment Ophthalmol 2010;38:683-7.

$37 \mathrm{Oh} \mathrm{HJ}$, Jang JY, Li Z, et al. Effects of umbilical cord serum eye drops in a mouse model of ocular chemical burn. Curr Eye Res 2012;37:1084-90.

38 Sharma N, Goel M, Velpandian T, et al. Evaluation of umbilical cord serum therapy in acute ocular chemical burns. Invest Ophthalmol Vis Sci 2011;52:1087-92.

39 Goto E, Shimmura S, Shimazaki J, et al. Treatment of superior limbic keratoconjunctivitis by application of autologous serum. Cornea 2001;20:807-10.

40 Pan Q, Angelina A, Zambrano A, et al. Autologous serum eye drops for dry eye. Cochrane Database Syst Rev 2013;8:CD009327. 
41 Kitazawa T, Kinoshita S, Fujita K, et al. The mechanism of accelerated corneal epithelial healing by human epidermal growth factor. Invest Ophthalmol Vis Sci 1990;31:1773-8

42 Pancholi S, Tullo A, Khaliq A, et al. The effects of growth factors and conditioned media on the proliferation of human corneal epithelial cells and keratocytes. Graefe Arch Clin Exp Ophthalmol 1998;236:1-8.

43 Imanishi J, Kamiyama K, Iguchi I, et al. Growth factors: importance in wound healing and maintenance of transparency of the cornea. Prog Retin Eye Res 2000;19:113-29.

44 Partal A, Scott E. Low-cost protocol for the production of autologous serum eye drops by blood collection and processing centres for the treatment of ocular surface diseases. Transfus Med 2011;21:271-7.

45 Noda-Tsuruya T, Asano-Kato N, Toda I, et al. Autologous serum eye drops for dry eye after LASIK. J Refract Surg 2006;22:61-6.

46 Brown SM, Bradley JC. The effect of autologous serum eye drops in the treatment of severe dry eye disease: a prospective randomized case-control study. Am J Ophthalmol 2005;140:565; author reply 565-6.

47 Schiffman RM, Christianson MD, Jacobsen G, et al. Reliability and validity of the Ocular Surface Disease Index. Arch Ophthalmol 2000;118:615-21.

48 Lee HR, Hong YJ, Chung S, et al. Proposal of standardized guidelines for the production and quality control of autologous serum eye drops in Korea: based on a nationwide survey. Transfusion 2014;54:1864-70.

49 NHS Blood and Transplant. Autologous Serum Eyedrops Service. 2008. http://www. nhsbt.nhs.uk/tissueservices/pdf/Autologous_Serum_Eyedrops_Service_leaflet\%20_ 21_10_2008.pdf (accessed Mar 2015).

50 Liu L, Hartwig D, Harloff S, et al. An optimised protocol for the production of autologous serum eyedrops. Graefes Arch Clin Exp Ophthalmol 2005;243:706-14.

51 Harritshøj LH, Nielsen C, Ullum H, et al. Ready-made allogeneic ABO-specific serum eye drops: production from regular male blood donors, clinical routine, safety and efficacy. Acta Ophthalmol 2014;92:783-6.

52 Pleyer U, Schlickeiser $S$. The taming of the shrew? The immunology of corneal transplantation. Acta Ophthalmol 2009;87:488-97.

53 Badami KG, McKellar M. Allogeneic serum eye drops: time these became the norm? Br J Ophthalmol 2012;96:1151-2.

54 Lagnado R, King AJ, Donald F, et al. A protocol for low contamination risk of autologous serum drops in the management of ocular surface disorders. $\mathrm{Br} J$ Ophthalmol 2004;88:464-5.

55 Sauer R, Blüthner K, Seitz B. [Sterility of non-preserved autologous serum drops for treatment of persistent corneal epithelial defects]. Ophthalmologe 2004;101:705-9.

56 Thanathanee 0, Phanphruk W, Anutarapongpan 0, et al. Contamination risk of $100 \%$ autologous serum eye drops in management of ocular surface diseases. Cornea 2013;32:1116-19.

57 Leite SC, De castro RS, Alves M, et al. Risk factors and characteristics of ocular complications, and efficacy of autologous serum tears after haematopoietic progenitor cell transplantation. Bone Marrow Transplant 2006;38:223-7.
58 Fischer KR, Opitz A, Böeck M, et al. Stability of serum eye drops after storage of 6 months. Cornea 2012;31:1313-18.

59 López-García JS, García-lozano I. Use of containers with sterilizing filter in autologous serum eyedrops. Ophthalmology 2012;119:2225-30.

60 Bradley JC, Simoni J, Bradley RH, et al. Time-and temperature-dependent stability of growth factor peptides in human autologous serum eye drops. Cornea 2009;28:200-5.

61 McDonnell PJ, Schanzlin DJ, Rao NA. Immunoglobulin deposition in the cornea after application of autologous serum. Arch Ophthalmol 1988;106:1423-5.

62 Welder JD, Bakhtiari P, Djalilian AR. Limbitis secondary to autologous serum eye drops in a patient with atopic keratoconjunctivitis. Case Rep Ophthalmol Med 2011;2011:576521.

63 Katzman $L R$, Jeng BH. Management strategies for persistent epithelial defects of the cornea. Saudi J Ophthalmol 2014;28:168-72.

64 Zimmermann R, Jakubietz M, Strasser E, et al. Different preparation methods to obtain platelet components as a source of growth factors for local application. Transfusion 2001;41:1217-24.

65 Anitua E. Plasma rich in growth factors: preliminary results of use in the preparation of future sites for implants. Int J Oral Maxillofac Implants 1999;14:529-35.

66 Anitua E, Andía I, Sanchez M, et al. Autologous preparations rich in growth factors promote proliferation and induce VEGF and HGF production by human tendon cells in culture. J Orthop Res 2005;23:281-6.

67 Hartwig D, Harloff S, Liu L, et al. Epitheliotrophic capacity of a growth factor preparation produced from platelet concentrates on corneal epithelial cells: a potential agent for the treatment of ocular surface defects? Transfusion 2004;44:1724-31.

68 Liu L, Hartwig D, Harloff S, et al. Corneal epitheliotrophic capacity of three different blood-derived preparations. Invest Ophthalmol Vis Sci 2006;47:2438-44.

69 Freire V, Andollo N, Etxebarria J, et al. In vitro effects of three blood derivatives on human corneal epithelial cells. Invest Ophthalmol Vis Sci 2012;53:5571-8.

70 Tanidir ST, Yuksel N, Altintas 0, et al. The effect of subconjunctival platelet-rich plasma on corneal epithelial wound healing. Cornea 2010;29:664-9.

71 Anitua E, Sanchez M, Merayo-lloves J, et al. Plasma rich in growth factors (PRGF-Endoret) stimulates proliferation and migration of primary keratocytes and conjunctival fibroblasts and inhibits and reverts TGF-beta1-Induced myodifferentiation. Invest Ophthalmol Vis Sci 2011;52:6066-73.

72 Anitua E, Muruzabal F, Pino A, et al. Biological stability of plasma rich in growth factors eye drops after storage of 3 months. Cornea 2013;32:1380-6.

73 Anitua E, Muruzabal F, De la fuente M, et al. Effects of heat-treatment on plasma rich in growth factors-derived autologous eye drop. Exp Eye Res 2014;119:27-34.

74 López-Plandolit S, Morales MC, Freire V, et al. Efficacy of plasma rich in growth factors for the treatment of dry eye. Cornea 2011;30:1312-17.

75 López-Plandolit S, Morales MC, Freire V, et al. Plasma rich in growth factors as a therapeutic agent for persistent corneal epithelial defects. Cornea 2010;29:843-8. 